\title{
Speech Acts as a Variety of Verbal Communication
}

\author{
Micheline Michel Magdy Baki* \\ michelinemichel_13@hotmail.com
}

\section{ABSTRACT}

Speech act theory, thought foreshadowed by the Austrian philosopher Ludwing Wittgenstien's views about language games, is usually attributed to the Oxford philosopher J. L. Austin. The basic ideas, which were formed by him in the late 1930s, were presented in his lectures given at Oxford in 1952- 54, and later in his William James lectures delivered at Harvard in 1955. Speech act is a part of pragmatics where there are certain aims beyond the words or phrases when a speaker says something. Speech acts are acts that refer to the action performed by produced utterances. People can perform an action by saying something . Through speech acts, the speaker can convey physical action merely through words and phrases. The conveyed utterances are paramount to the actions performed.

KEY WORDS: Pragmatics, Speech acts, Conveyed utterances

$$
\text { ب باحثة دكتوراة ـ معهد المعارف العالى للغات و الترجمة * }
$$

(Speech Acts as a Variety of Verbal Communic ation...) Micheline Michel Magdy 
Speech act theory, thought foreshadowed by the Austrian philosopher Ludwing Wittgenstien's views about language games, is usually attributed to the Oxford philosopher J. L. Austin. The basic ideas, which were formed by him in the late 1930s, were presented in his lectures given at Oxford in 1952-54, and later in his William James lectures delivered at Harvard in 1955. These lectures were finally published posthumously as How to do things with words in 1962. After his death in 1960, Austin's ideas were refined, systematized, and advanced especially by his Oxford pupil, the American philosopher John R. Searle. Simply stated, the central tenet of speech act theory is that the uttering of a sentence is, or is part of, an action within the framework of social institutions and conventions. Put in slogan form, saying is (part of) doing, or words are (part of) deeds. (Concise Encyclopedia, 705)

\section{Performatives versus constatives}

\subsection{The performative / constative dichotomy}

In the 1930s, a very influential school of thought in philosophy was logical positivism, developed by a group of philosophers and mathematicians principally in Vienna. One of the central doctrines of logical positivism is what is now called the descriptive fallacy, namely, the view that the only philosophically interesting function of language is that of making true or false statements. A particular version of the descriptive fallacy is the so- called verificationist thesis of meaning, namely, 
the idea that 'unless a sentence can, at least in principle, be verified (i.e. tested for its truth or falsity), it was strictly speaking meaningless' (Levinson 1983: 227; Lyons 1995: 173). On such a view, sentences like those in (4.1) are simply meaningless, because they are not used to make verifiable or falsifiable propositions. Instead they express subjective judgments.

(4.1) a. Shouting and screaming at your children is wrong.

b. Elizabeth is more beautiful than Mary.

c. Getting married and having children is better than having children and getting married.

It was against this philosophical background that Austin set about developing his theory of speech acts (Austin 1962). He made two important observations. First, he noted that some ordinary language sentences such as those in (4. 2) are not employed to make a statement, and as such cannot be said to be true or false.

(4.2) a. Good morning!

b. Is she a vegetarian?

c. Put the car in the garage, please.

Secondly and more importantly, Austin observed that there are ordinary language declarative sentences that resist a truth conditional analysis in a similar fashion. The point of uttering such sentences is not just to say things, but also actively to do things. In other words, such utterances have both a descriptive and an effective aspect. Accordingly, Austin called them 
performatives, and he distinguished them from assertions, or statement making utterances, which he called constatives.

\subsection{The performative hypothesis}

In order to account for implicit performatives, an analysis known as the performative hypothesis was put forward in the 1970s. The basic idea of the hypothesis is that underlying every sentence there is a hidden matrix performative clause of the form given in:

- "I (hereby) Vp you (that) S"

Where $\mathrm{Vp}$ is a performative verb, and $\mathrm{S}$ is a complement clause. The performative verb, which is in the indicative mood, active voice, and simple present tense, will always make explicit what is implicit, through the matrix performative clause can be deleted without meaning being changed (e.g. Ross 1970, Lakoff 1972, Sadock 1974).

\section{Austin's felicity conditions on performatives}

As mentioned, it makes no sense to call a performative true or false. Nevertheless, Austin noticed that for a performative to be successful or felicitous, it must meet a set of conditions. For example, one such condition for the speech act of naming is that the speaker must be recognized by his or her community as having the authority to perform that act; for the speech act of ordering, the condition is that the speaker must be in authority over the addressee, and finally, for the speech act of promising, one condition is that what is promised by the speaker must be 
something the addressee wants to happen. Austin called these conditions felicity conditions. In other words, felicity conditions are conditions under which words can be used properly to perform actions. ( Encyclopedia of Language and Linguistics, 2005)

Austin distinguished three different types of felicity conditions (Austin 1975: 14-15).

(4.3) Austin's felicity conditions on performatives

a. (i) There must be a conventional procedure having a conventional effect.

(ii) The circumstances and persons must be appropriate, as specified in the procedure.

b. The procedure must be executed (i) correctly and (ii) completely.

\section{c. Often}

(i) the person must have the requisite thoughts, feelings and intentions, as specified in the procedure, and

(ii) if consequent conduct is specified, then the relevent parties must so do.

Violation of any of the conditions in (4.1) will render a performative unhappy or infelicitous. If conditions A or B are not observed, then what Austin described as a misfire takes place. For instance, in England, a registrar conducting a marriage ceremony in an unauthorized place will violate condition A (i), thus committing a misfire. The same is true for a clergyman baptizing a wrong baby, because in this case, condition A (ii) is not 
fulfilled. Next, as an illustration of a violation of condition B (i), consider the case of a bridegroom not saying the exact words that are conventionally laid down at a marriage ceremony. As to condition B (ii), it dictates that the procedure must be complete.

\section{Locutionary, illocutionary, and perlocutionary speech acts}

The initial distinction made by Austin between performatives and constatives was soon to be rejected by him in favour of a general theory of speech acts. In fact, as pointed out by Levinson (1983: 231), there are two internal shifts in Austin's arguments. First, there is a shift from the view that performatives are a special class of sentences/ utterances with peculiar syntactic and semantic properties to the view that there is a general class of performatives that encompasses both explicit and implicit performatives, the latter including many other types of sentence/ utterance. The second shift is from the performative/ constative dichotomy to a general theory of speech acts, of which the various performatives and constatives are just special subcases. (Huang, 126)

What led Austin to abandon the performative/ constative dichotomy? In the first place, he noted that like performatives, constatives are also subject to the felicity conditions stated in (4.3). Recollect so called Moore's paradox as illustrated by (4.4).

(4.4) Princess Diana died in a fatal car crash in Paris with Dodi Al Fayed, but I don't believe it. 
This utterance is infelicitous because it violates condition C (i) in (4.3) above. In the same vein, if someone utters (4.5) when he or she knows that John does not in fact have a wife, then its presupposition will not go through. The reason the presupposition fails to carry through is that A (ii) in (4.3) above is not adhered to. (4.5) I'm sure John's wife is a feminist.

Secondly, Austin observed that performatives and constatives may be impossible to distinguish even in truth conditional terms. On the one hand, there are 'loose' constatives that may not be assessed strictly by means of truth conditions, as in (4.6).

(4.6) a. (Austin 1962) France is hexagonal.

b. John is bald.

c. London is sixty miles from where I live.

France is not, strictly speaking, hexagonal. John still has quite a few wispy strands of hair on his head. London may not be exactly sixty miles from where the speaker lives. Thus, statements like in (4.6) can only be said to be more or less, or roughly, true. On the other hand, there are utterances like those in (4.7) that pass the "hereby" test, and therefore they are performatives by definition, but that nevertheless are used to state or assert. In cases, the performatives must be counted simultaneously as constatives.

(4.7) a. I hereby state that John is growing GM crops. 
b. I hereby tell you that the prime minister is not going to stand down.

c. I hereby hypothesize that there is water on Mars.

On this basis of such evidence, Austin concluded that constatives are nothing but a special class of performatives, and that the two way distinction between performatives, as action performers, and constatives, as truth bearers, can no longer be maintained. (Huang, 127)

Consequently, Austin claimed that all utterances, in addition to meaning, whatever they mean, perform specific acts via the specific communicative force of an utterance. Furthermore, he introduced a threefold distinction among the acts one simultaneously performs when saying something. (Huang, 127)

(4.8) Three facets of a speech act.

(i) Locutionary act: the production of a meaningful linguistic expression.

(ii) Illocutionary act: the action intended to be performed by a speaker in uttering a linguistic expression, by virtue of the conventional force associated with it, either explicitly or implicitly.

(iii) Perlocutionary act: the bringing about of consequences or effects on the audience through the uttering of a linguistic expression, such consequences or effects being special to the circumstances of the utterance. 
A locutionary act is the basic act of speaking, which itself consists of three related subacts, They are (i) a phonic act of producing an utterance inscription, (ii) a phatic act of composing a particular linguistic expression in a particular language, and (iii) a rhetic act of contextualizing the utterance inscription (Austin 1962, Lyons 1995: 177-85). In other words, first of these three subacts is concerned with the physical act of making a certain sequence of vocal sounds (in the case of spoken language) or a set of written symbols (in the case of written language). The second refers to the act of constructing a well formed string of sounds/ symbols, whether it is a word, phrase or sentence, in a particular language. The third subact is responsible for tasks such as assigning reference, resolving deixis, and disambiguating the utterance inscription lexically and/ or grammatically. These three subacts correspond broadly to the three distinct levels and modes of explanation in linguistic theory, namely, phonetics/ phonology, morphology/ syntax, and semantics/ pragmatics.

When we say something, we usually say it with some purpose in mind. This is the illocutionary act. In other words, an illocutionary act refers to the type of function the speaker intends to fulfill, or the type of action the speaker intends to accomplish in the course of producing an utterance. It is an act defined within a system of social conventions. In short, it is an act accomplished in speaking. Examples of illocutionary acts include accusing, apologizing, blaming, congratulating, giving permission, joking, 
nagging, naming, promising, ordering, refusing, swearing, and thanking. The functions or actions just mentioned are also commonly referred to as the illocutionary force or point of the utterance. Illocutionary force is frequently conveyed by what Searle (1969) called an illocutionary force indicating device (IFID), the most direct and conventional type of which is an explicit performative. Indeed, the term speech act in its narrow sense is often taken to refer specifically to illocutionary acts.

It should be mentioned at this point that the same linguistic expression can be used to carry out a wide variety of different speech acts, so that the same elocutionary act can count as having different illocutionary forces in different contexts. Depending on the circumstances, one may utter (4.9) below to make a threat, to issue a warning or to give an explanation.

(4.9) The gun is loaded.

In fact, Alston (1994) argued that the meaning of a sentence consists in its having a certain illocutionary act potential (IAP)that is closely and conventionally associated with its form. On this view, to know what a sentence means is to know what range of illocutionary acts it can conventionally be used to perform (see also Recanati 2004b).

Conversely, the same speech act can be performed by different linguistic expressions, or the same illocutionary force can be realized by means of different locutionary acts. The 
utterances in (4.10), for example, illustrate different ways of carrying out the same speech act of requesting.

(4.10) (At ticket office in railway station)

a. A day return ticket to Oxford, please.

b. Can I have a return ticket to Oxford, please?

c. I'd like a day return ticket to Oxford.

Finally, a perlocutionary act concerns the effect an utterance may have on the addressee. Put slightly more technically, a perlocution is the act by which the illocution produces a certain effect in or exerts a certain influence on the addressee. Still another way to put it is that a perlocutionary act represents a consequence or by product of speaking, whether intentional or not. It is therefore an act performed by speaking. For example, in an armed bank robbery, a robber may utter (4. 9) to get the cashier to open the safe. This effect of the act performed by speaking is also generally known as the perlocutionary effect.

While there are unclear cases, the main differences between illocutions and perlocutions can be summed up as follows. In the first place, illocutionary acts are intended by the speaker, while perlocutional effects are not always intended by him or her. Secondly, illocutionary acts are under the speaker's full control, while perlocutionary effects are not under his or her full control. Thirdly, if illocutionary acts are evident, they become evident as the utterance is made, while perlocutionary effects are usually not evident until after the utterance has been made 
(Hurford and Heasley 1983: 247). Fourthly, illocutionary acts are, in principle, determinate while perlocutionary effects are often indeterminate. Finally, illocutionary is tied to linguistic forms.

\section{Searle's felicity conditions on speech acts}

Searle (1969) took the view that the felicity conditions put forward by Austin are not only ways in which a speech act can be appropriate or inappropriate, but they also jointly constitute the illocutionary force. Put in a different way, the felicity conditions are the constitutive rules, rules that create the activity itself, of speech acts. On Searle's view, to perform a speech act is to obey certain conventional rules that are constitutive of that type of act. Searle developed the original Austinian felicity conditions into a neo- Austinian classification of four basic categories, namely, (i) propositional content, (ii) preparatory condition, (iii) sincerity condition, and (iv) essential condition. As an illustration of these conditions, consider (4.11) and (4.12). (Haung, 131)

(4.11) Searle's felicity conditions for promising.

(i) Propositional content: future act $A$ of $S$

(ii) Preparatory: (a) $H$ would prefer $S$ 's doing $A$ to his not doing $A, \quad$ and $S$ so believes (b). It is not obvious to both $S$ and $H$ that $S$ will do $A$ in the normal course of events.

(iii) Sincerity: $S$ intends to do $A$

(iv) Essential: the utterance of $e$ counts as an undertaking to $\operatorname{do} A$ 
where $S$ stands for the speaker, $H$ for the hearer, $A$ for the action, and $e$ for the linguistic expression.

(4.12) Searle's felicity conditions for requesting

(i) Propositional content: future act $A$ of $H$

(ii) Preparatory: (a) $S$ believes $H$ can do $A$ (b) It is not obvious that $H$ would do $A$ without being asked.

(iii) Sincerity: $S$ wants $H$ to do $A$

(iv) Essential: the utterance of $e$ counts as an attempt to get $H$ to do $A$.

The propositional content condition is in essence concerned with what the speech act is about. That is, it has to do with specifying the restrictions on the content of what remains as the 'core' of the utterance (i.e Searle's propositional act) after the illocutionary act part is removed. For a promise, the propositional content is to predicate some future act of the speaker, whereas in the case of a request, it is to predicate some future act of the addressee. The preparatory conditions state the real world prerequisites for the speech act. For a promise, these are roughly that the addressee would prefer the promised action to be accomplished, that the speaker knows this, but also that it is clear to both the speaker and the addressee that what is promised will not happen in the normal course of action. In the case of a request, the preparatory conditions mean that the speaker has reason to believe that the addressee has the ability to carry out the action requested, and that if the addressee is not asked, he or she will not 
performed the action. Next, the sincerity condition must be satisfied if the act is to be performed sincerely. Thus, when carrying out an act of promising, the speaker must genuinely intend to keep the promise. When making a request, the speaker wants the addressee to do the requested action. Notice that if the sincerity condition is not fulfilled, the act is still performed, but there is an abuse, to use Austin's term. Finally, the essential condition defines the act being performed in the sense that the speaker has the intention that his or her utterance will count as the identifiable act, and that this intention is recognized by the addressee. Thus, in the case of a promise, the speaker must have the intention to create an obligation to act, and for a request, the speaker must intend that his or her utterance counts as an attempt to get the addressee to do what is requested. Failure to meet the essential condition has the consequence that the act has not been carried out.

\section{Searle's typology of speech acts}

Can speech acts be classified, and if so, how? Austin (1962) grouped them into five types: (i) verdictives: giving a verdict, (ii) exercitives: exercising power, rights, or influence, (iii) commissives: promising or otherwise undertaking, (iv) behabitives: showing attitudes and social behaviour, and (v) expositives: fitting an utterance into the course of an argument or conversation. Since then, there have been many attempts to 
systematize, strengthen, and develop the original Austinian taxonomy. Some of these new classifications are formulated in formal / grammatical terms, others in semantic / pragmatic terms, and still others on the basis of the combined formal / grammatical and semantic / pragmatic modes. Of all these (older and newer) schemes, Searle's (1975a) neo- Austinian typology of speech acts remains the most influential. (Encyclopedia of Language and Linguistics, 921)

Under Searle's taxonomy, speech acts are universally grouped into five types along four dimensions: (i) illocutionary point or speech act type, (ii) direction of fit or relationship between words and word, (iii) expressed psychological state, and (iv) propositional content.

(i) Representatives are those kinds of speech act that commit the speaker to the truth of the expressed proposition, and thus carry a truth value. They express the speaker's belief. Paradigmatic cases include asserting, claiming, concluding, reporting, and stating. In performing this type of speech act, the speaker represents the world as he or she believes it is, thus making the words fit the world of belief. Representatives are illustrated in (4.13).

(4.17) a. Chinese characters were borrowed to write other languages, notably Japanese, Korean and Vietnamese.

b. Francis Crick and Jim Watson discovered the double helix structure of DNA. 
c. The soldiers are struggling on through the snow.

(ii) Directives are those kinds of speech act that represent attempts by the speaker to get the addressee to do something. They express the speaker's desire / wish for the addressee to do something. Paradigmatic cases include advice, commands, orders, questions, and requests. In using a directive, the speaker intends to elicit some future course of action on the part of the addressee, thus making the world match the words via the addressee. Directives are exemplified in (4.14).

(4.14) a. Turn the TV down.

b. Don't use my electric shaver.

c. Could you please get that lid off for me?

(iii) Commissives are those kinds of speech act that commit the speaker to some future course of action. They express the speaker's intention to do something. Paradigmatic cases include offers, pledges, promises, refusals, and threats. In the case of a commissives, the world is adapted to the words via the speaker him or herself. Examples of commissives are presented in (4.15).

(4.15) a. I'll be back in five minutes.

b. We'll be launching a new policing unit to fight cybercrime on the internet soon.

c. I'll never buy you another computer game.

(iv) Expressives are those kinds of speech act that express a psychological attitude or state in the speaker such as joy, 
sorrow, and likes / dislikes. Paradigmatic cases include apologizing, blaming, congratulating, praising, and thanking. There is no direction of fit for this type of speech act.

(4.16) a. Well done, Elizabeth!

b. I'm so happy.

c. Wow, great!

(v) Declarations (or declaratives) are those kinds of speech act that affect immediate changes in some current state of affairs. Because they tend to rely on elaborate extra linguistic institutions for their successful performance, they may be called institutionalized performatives. In performing this type of speech act, the speaker brings about changes in the world; that is, he or she affects a correspondence between the propositional content and the world. Paradigmatic cases include bidding in bridge, declaring war, excommunicating, firing from employment, and nominating a candidate. As to the direction of fit, it is both words to world and world to words.

(4. 17) a. President: I declare a state of national emergency.

b. Chairman: The meeting is adjourned.

c. Jury foreman: We find the defendant not guilty.

Illocutional point, direction of fit, and expressed psychological state can be summarized in (4. 18) (see Vanderveken 1994 for a formalization in terms of illocutionary logic). 
(4. 18) - Illocutionary point: Representative, Directives, Commissives, Expressives, Declarations.

- Direction of fit: words to world, world to words, world to words, none, both.

- Expressed psychological state: belief (speaker), desire (addressee), intention (speaker), variable (speaker), none (speaker).

\section{Indirect speech acts}

\section{1. What is an indirect speech act?}

Most of the world's languages have three basic sentence types: (i) declarative, (ii) interrogative, and (iii) imperative. In some languages, the three major sentence types are distinguished morphologically and / or syntactically. Somali provides an example of such a language.

(4.19) (Saeed 2003: 237)

a. Warkii waad dhegeysatay.

news the DECL-you listen to- 2SG-PAST

'You listened to the news.'

b. Warkii miyaad dhegeysatay?

news the Q- you listen to-2SG-PAST

'Did you listen to the news?'

c. Warkii dhegeyso.

news the listen to-2SG-IMPV

'Listen to the news.'

(Speech Acts as a Variety of Verbal Communic ation...) Micheline Michel Magdy 
In (4.19), the declarative format is marked by waa, the interrogative format is indicated by $m a$, and the imperative format is indicated with a zero marking (Saeed 2003: 237). Another example is provided by Greenlandic.

(4. 20) (Sadock and Zwicky 1985)

a. Igavoq.

cook- INDIC -3SG

'He cooks'.

b. Igava.

cook -Q- 3SG

'Does he cook?'

In (4. 20), the declarative and interrogative are differentiated by means of separate personal suffixes (Sadock and Zwicky 1985). Finally, in Lakhota, the difference between a 'declarative' with an indefinite pronoun and an interrogative with an interrogative pronoun is marked by the adding of a sentence final question particle.

\section{2. How is an indirect speech act analyzed?}

Roughly, there are three main approaches. The first is to assume the existence of a dual illocutionary force (as proposed by Searle 1975b). On this indirect speech acts have two illocutionary forces, one literal or direct, and the other non- literal or indirect. While the literal force is secondary, the non- literal force is primary. Next, whether an utterance operates as an indirect speech 
act or not has to do with the relevant felicity conditions. For example, (4.22) Can you pass the salt?, both infringes the felicity condition for the speech act of questioning and queries the preparatory condition for that of requesting. This explains why it can function as an indirect speech act whereas (4.23), for example, cannot. The reason is that, in the case of (4.23), felicity conditions are irrelevant.

(4.23) (Searle 1975b)

Salt is made of sodium chloride.

Finally, on Searle's view, a speaker's performing and an addressee's understanding an indirect speech act always involves some kind of inference. The question that arises next is how this inference can be computed. Searle's suggestion is that it can be computed along the general lines of the rational, cooperative model of communication articulated by Grice.

One interesting characteristic of indirect speech acts is that they are frequently conventionalized (Morgan 1978). This can be illustrated by the fact of various, apparently synonymous linguistic expressions, only one may conventionally be used to convey an indirect speech act. Consider (4.24).

(4.24) a. Are you able to pass the salt?

b. Do you have the ability to pass the salt?

Under Searle's analysis both (4. 23 a) and (4.23 b) would be expected to be able to perform the indirect speech act of requesting, because (i) they are largely synonymous with (4. 22), 
and (ii) they, too, inquire about the satisfaction of the addressee based preparatory condition for making a request. But this expectation is not fulfilled.

Searle's response to this puzzle is that there is also a certain degree of conventionality about indirect speech acts, and this may be accounted for in terms of convention of use / meaning. Inspired by this insight of Searle's, Morgan (1978) developed a notion of short circuited implicature to cover inference involved in cases like (4. 22). In these cases, while the relevant conversational implicature is, in principle, is not practice calculated. From a linguistic point of view, then the conventionality here is correlated with the possible occurrence of please. While please can be inserted before the verb pass in (4.21) and (4.22), it cannot be in (4.24), as shown in (4.25).

(4.25) a. I request you to please pass the salt.

b. Please pass the salt.

c. Can you please pass the salt?

d. Are you able to please pass the salt?

e. Do you have the ability to please pass the salt? 


\section{REFERENCES}

Aichison, Jean. (1991). "Language Change: Progress or Decay?" New York: Cambridge University Press.

Alexander, L.G. (1994). "Longman English Grammar Practice”. Essex: Longman.

Barber, Charles. (1999). "The English Language: A Historical Introduction". Cambridge: Cambridge University Press.

Bell, Roger T. (1993). "Translation and Translating: Theory and Practice”. London: Longman.

Blake, N.F. (1996). "A History of the English Language”. London: Macmillan Press Ltd.

Blakemore, Diane. (1990). "Linguistic Form and Pragmatic Interpretation: the Explicit and the Implicit." In Hickey, ed., pp. 28-51.

Burton, S.H. (1974). "The Criticism of Poetry”. London: Longman.

Cameron, Deborah. (1992). "Feminism and Linguistic Theory". London: Macmillan.

Chalker, Sylvia and Edmund Weiner. (1994). "The Oxford Dictionary of English Grammar". Oxford, NY: Oxford University Press.

Clark, John O.E. (1990). “Dictionary of English Usage”. London: Harrap.

Cohen, Andrew D. (1996). "Speech Acts." In McKay and Hornberger, eds., pp. 383-420)

(Speech Acts as a Variety of Verbal Communic ation...) Micheline Michel Magdy 
Cruse, D.A. (1989). "Lexical Semantics”. Cambridge: Cambridge University Press.

Fabb, Nigel and Others, eds. (1987). "The Linguistics of Writing". New York: Methuen Inc.

Flora, Klein-Andren ed. (1983). "Discourse Perspectives on Syntax”. Now York: Academic Press.

Fowler, H.W. (1983). "A Dictionary of Modern English Usage”. New York: Oxford University Press.

Fromkin, Victoria and Robert Rodman. (1978). "An Introduction to Language". New York: Holt, Rinehart and Winston.

Gindin, James. (1988). “William Golding”. London: Macmillan.

Golding, William (1955). "The Inheritors". London: Faber and Faber.

Golding, William. "Lord of the Flies". Orlando, Florida: Harcourt Brace Jovanovich (1955), London: Faber and Faber (1954).

Greenbaum, Sidney (Ed.). (2000). "The Oxford Reference Grammar". Oxford: Oxford University Press.

Grice, H.P. (1989) "Studies in the way of Words". Cambridge MA: Harvard University Press.

Grundy, Peter. (1995). “Doing Pragmatics”. New: York: Edward Arnold. 
Hickey, Leo. (Ed.). (1990). "The Pragmatics of Style”. New York: Routledge.

Huang, Yan. (2013). "Pragmatics". Oxford: Oxford University Press.

Kaplan. Robert B.. ed. (1980). "On the Scope of Applied Linguistics”. Rowley, Massachusetts: Newbury House Publishers, Inc.

Leech, Geoffrey N. (1983). "Principles of Pragmatics”. London: Longman.

Levinson, Stephen C. (1992). "Pragmatics". New York: Cambridge University Press, 1992.

Moody, H.L.B. (1982). "Varieties of English: Practice in Advanced Uses of English”. London: Longman.

Tiger, Virginia. (1974). "William Golding: The Dark Fields of Discovery”. London: Marion Boyars. 


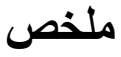

يعكس الأدب نقافة المجتم؟؛ يظهر ذلك من خلال استعراض بعض النظريات اللغوية لإثبات مدى تأثنر السياق على نطور لغة الأشخاص. و من ضمن هذه النظريات ، النظرية البرجمانية و النظرية الإفتراضية و الإثارة و نظربة الترابط المعنوي ونظرية الاتساق السطحي. وتطبيق هذه الدراسة اللغوية يكثف عن مواقف

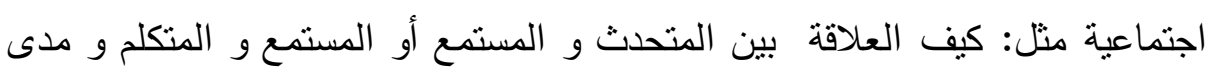

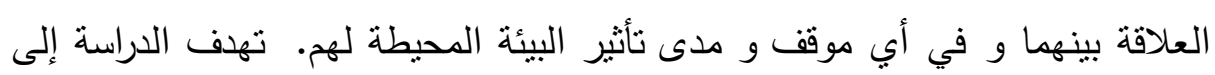
إثبات تأثير اللغة على المجتمع وبيان أثز استخدم الأثخاص في محاولة لإثبات أن اللغة تختلف باختلاف المواقف و العلاقة الاجتماعية بين الأشخاص. الكلمات المفتاحية: النظرية الافتراضية ، الإثارة، نظرية الترابط، نظرية الاتساق السطحي 